\title{
Exploring Factors Leading to Customer Loyalty to Fashion Brands: A Case Study of Harare, Zimbabwe
}

\author{
Nomagugu Ndlovu1, Tarirai Dandira² \& Felisia Chimbindi ${ }^{3}$ \\ ${ }^{1}$ Chinhoyi University of Technology Student \\ ${ }^{2}$ Senior Lecturer, Chinhoyi University of Technology. \\ ${ }^{2}$ Senior Lecturer, Chinhoyi University of Technology. Correspondence author. \\ Email: felisiachimbindi5814@gmail.com
}

\begin{abstract}
The study sought to analyze the factors that lead to customer loyalty to fashion brands in Harare, Zimbabwe. The study made use of a qualitative research approach. Data was collected using unstructured interview and focus group discussion from five managers and ten fashion consumers for five fashion retail shops in Harare selected through purposive sampling technique. Findings were analyzed thematically. The findings reflected that customer loyalty to fashion brands was mostly influenced by economic conditions such as inflation, wages, market interest rates, demographics, customer satisfaction, decrease in disposable income and buying power. Strategies such as product promotions and provision of flexible hire purchase facilities among others suggestions emerged from the findings as ways to improve customer loyalty and viability of the fashion business. The study recommends fashion retailers to formulate a fashion retailer's board responsible for organizing forums to discuss issues regarding customer brand loyalty and fashion retail business improvement. The study findings helped to develop a model that may help in improving fashion products consumption and customer loyalty.
\end{abstract}

\section{Key words}

Brand, fashion brand, brand loyalty, customer, fashion retail shop.

\section{Introduction}

Zimbabwe's departmental stores have been on a sinking ship from 2017 to 2020 ending a colourful shopping experience that was once popular for middle income and big elite consumers. Several major retail shops such as Woolworths, Marcy's, HM Barbous, Greater man's, Meikles, Clicks and a few others went down in the clothing sector (Mirriam, 2020). For example in Harare, people would buy brands like Pepkor, Versace, Gucci and Kelsoin most of the above mentioned shops. Most of the fashion retails closed for renovations and that is how the departmental stores like Greatermans, operated by the Meikles group along Harare's Jaison Moyo Avenue exited the fashion retail scene. Later customers discovered that the renovations were in fact meant to change the line of business as the retail shops morphed into supermarkets (Fidelity, 2019). It is not clear as to whether such brands found in the closed shops are sold in the malls and in existing shops 
such as Edgars or not. The fashion customers are free to purchase brands of choice from any market place as long as they get the desired product brand.

The textile and clothing sector plays an extremely significant role in Zimbabwe in terms of employment creation, value addition and foreign exchange earnings. Hence, factors such as customer loyalty play a critical role in the viability of fashion outlets. Most of the existing fashion retails are battling to maintain customer loyalty to fashion brands since most consumers can no longer afford to buy new fashion products (Kuwaza, 2019).This led to reduction of sales in the most existing large retail shops due to emergency of open clothing markets in the streets of towns and at growth points across the country. Besides, the consumers are facing economic hardships and impact of COVID 19 pandemic that has affected the business environment. This triggered the researchers to establish and analyze the factors that lead to customer loyalty to fashion brands in Zimbabwe to find out how retailers and consumers can work to improve customer loyalty to fashion brands to effectively contribute to the economy of the country and maintain a viable fashion business.

Customer loyalty is more than simple repurchasing however, customers may purchase a brand due to situational constraints, lack of viable alternatives or out of convenience. Brand loyalty exists when consumers have high relative attitude towards the brand (Maslam, 2015). When customers are loyal to a certain brand, they repeatedly purchase the brand over a period of time. Therefore, the need to conduct this study to establish the factors that lead to customer loyalty to fashion brands and suggest strategies to enhance customer loyalty to fashion brands. The research questions that guided this study are presented below

\section{Research questions}

1. What are the factors that lead to customer loyalty to fashion brands?

2. What strategies can be put in place to maintain customer loyalty within the brands offered by clothing retail outlets in Zimbabwe?

\section{Literature Review}

\section{Theoretical framework}

Saunders (2017) articulates that a theoretical framework connects the researcher to existing knowledge by simply describing phenomenon. The researchers used Revealed preference theory by Samuelson (1938) to provide scientific investigation for the study to analyze the factors that lead to customer loyalty.

Revealed preference is an economic theory of consumption behavior which asserts that the best way to measure consumer preferences is to observe their purchasing behavior. Revealed preference theory constructs utility functions that rationalize empirical observations of consumer choices and consumer budget constraints (Samuelson, 1938, 1948; Little, 1949; Houthakker, 1950 $\&$ Afriat, 1967). The theory works on the assumption that consumers consider a set of alternatives before making a purchasing decision. Given that a consumer chooses on the option out of the set, this option should be the preferred option (Akin, 2015). In this regard the fashion consumers 
have to choose brands of fashion products they prefer from a wide range of products basing on reasons relayed in this study. Their choice to be loyal to specific product brands may depend on product performance, aesthetic value and on customer constraints. In some situations consumers may give first preference to basic goods such as food, sanitation and health services or they may be opting for other fashion brands besides the brands offered by their suppliers for various reasons. Consumers' preference for alternative brands may also be their voice to show poor performance of the original brands they used to purchase or extinction of the brands in the shops. There is always justification for consumers' change of product brand preferences. The paragraphs below discusses the term customer loyalty.

\section{Customer loyalty}

Customer loyalty is the likelihood of previous customers to continue to buy from a specific organization, brand, branch or factory (Ahmad, 2018). It is the willingness to buy a brand frequently over all others. This is typically due to the consumer's delightful and remarkable experiences they have with that brand. Customer loyalty is something all companies should aspire in order to have lasting clients. The point of departure for-profit making business is to attract and keep happy customers who continuously buy your products to drive revenue. If fashion retailers attract and keep customers happy continuously this helps them maintain their customers' loyalty to fashion brands they offer.

Customer loyalty also fosters a strong sense of trust between the brand and the supplier. When customers choose to frequently return to an indivudual's company, the value they are getting out of the relationship outweighs the potential benefits they would get from one of their competitors (Bernazzani, 2017). Customer loyalty is more than simple repurchasing, however, customers may purchase a brand due to situational constraints, lack of viable alternatives or out of convenience (Maslam, 2015).Therefore customer loyalty to product brand is when customers are not open to pitches from competing companies. It is also the result of having a consumer's consistent emotional attachment, physical attribute based satisfaction and perceived value of an experience, in using the product or service (Khadka, 2017). However, with closure of most fashion retail shops in Zimbabwe which used to offer high quality fashion brands and emergency of open markets offering cheap first hand and second hand products, it was imperative for the researchers to find out factors that affect customer loyalty for fashion brands in Zimbabwe. The section below presents factors that lead to customer loyalty.

\section{Factors leading to customer loyalty Customer satisfaction}

Factors leading to customer loyalty include customer satisfaction, demographics, elasticity and switching costs, inflation, market rates and disposable income. Satisfaction is an important influencing factor of customer loyalty that creates a long-term relationship between the customer and the product thereby influencing the success of the business. Customer satisfactions differ according to the customers' needs (Maslam, 2015). A customer may value fitness of a fashion product more than the product's durability or vice versa. One may consider functionality of the product against the products aesthetic value. The price, value and availability according to 
customers' expectations also influence on creating satisfaction (Maslam, 2015). The on-going satisfaction always determines customer loyalty towards the products or services and it is cheaper to make satisfied customers happy than acquiring customer satisfaction with a product (Zeleke, 2015).When the customer gets quality products or maximum profits from the products with minimum price then there occurs high customer satisfaction that leads to high customer loyalty as well as a close relationship between customers and suppliers that may last long. However, when the market gets flooded with new product brands, customer loyalty to the original brands may be affected as the customers may go for the new products. As such the ability of the new products to satisfy the customers through product performance may also affect customers' loyalty to the new product. Elasticity is another factor that affects customer loyalty to fashion brands.

\section{Elasticity}

If the services or products offered by a company are common and carry similar features to other products, the customers will move to find another company with special and unique features (Custer, 2017). Therefore, the company should have the motive to provide the products and services with unique and specific features to their customers. The customers, who are not satisfied with the products and services, try to research a lot before investing in the products, than only make decision on using the products and services. In analysing the factors that affect customer loyalty to fashion brands the researchers also looked at whether the fashion retailers are taking measures to maintain customer loyalty to fashion brands they sell. Demographics also has an influence to customer loyalty to fashion brands.

\section{Demographics}

Involves aspects like age, income, nationality, sex and location. It is predicted that less affluent customers are more loyal than the most affluent ones because they cannot afford the risk of moving to different brands fearing unknown performance of new products and those products they have not used before (Arief, 2019). Generally, the older customers are likely to last longer using the same product than younger customers because the younger customers always want to test the new ones since they have not developed confidence in use of products they have used for a shot time (Aslam, 2011). Nowadays, there are lots of competitors in the business where the customers find similar products in the same location. In such a situation the products with high technologies, advertisements and customer services are able to build good and lasting relationship with the customers. This insights retailers to work very hard to grab and maintain their customers.

\section{Depreciating disposable income}

It is money left from an individual's income after paying taxes. If disposable income increases, households have more money to either save or spend which naturally leads to growth in consumption (Creswell, 2016). It is also of much influence to customer loyalty because it determines the amount of money used to spend on fashion brands by customers. Disposable income has got factors influencing it which can also lead to decline in customer loyalty. Such factors include inflation, interest rates, market interest rates, wages and propensity to consume (Weber, 2015). Inflation affects private consumption through its influence on real income. Both inflation and inflation expectations may predetermine consumption decisions and affect 
5 | Exploring Factors Leading to Customer Loyalty to Fashion Brands: A Case Study of Harare, Zimbabwe

significantly private consumption in absolute terms and in its commodity structure (Veronese, 2013). For example Weber (2015) proved that households, expecting higher inflation are more likely to buy durables compared to households that expect constant or decreasing inflation.

Interest rates also influence disposable income as they have been included into the long-run consumption functions in many studies (Sawyer, 2008). Keynes (2000) stated that interest rates have little influence on consumption decisions, while Blare( 2007) proved that higher interest rates discourage consumption significantly, raising savings and vice versa. An increase in interest rates leads to more savings by consumers which mean they will have less money to spend. If disposable income depreciates it affects the buying behavior of customers which also affects fashion retails' business performance.

Fiscal expansion is also another factor that affects disposable income as it stimulates consumption from both demand and supply sides. If the government increases social spending, this leads to higher disposable income and may increase private consumption both in short and medium rum (Alan, 2013). Investment in infrastructure or spending on small and medium enterprises support influence from the supply side, generating a positive response on output in medium- and longterm perspective (Chetty, 2013). Unemployment causes a drop in income, generating a need for liquidity (Noel, 2017). Thus, household final consumption expenditures may decrease. When household final consumption expenditures decrease the fashion retails get affected in the sense that consumers may go for basic goods only.

Wage and propensity to consume is also another factor that affects disposable income. Classical economists laid stress on the stimulating effects of wage cuts on the propensity to consume (Alan, 2013). Wage cuts and wage increase influence the ability of consumers to spend on commodities. Disposable income has a lot of factors that affect it, however analyzing the situation in Zimbabwe is of great importance as the level of disposable income affects buying behavior of fashion consumers to a greater extent. Economic challenges of the country lead people to be paid salaries which are not enough to fulfill their needs and wants thus resulting in a sharp decrease of disposable income (Nyoni, 2008).

Disposable income affects the customer's buying power, the amount of money a person can use to invest in securities. That can include money the investor borrows in order to buy securities. It is the quantity of goods or services that a dollar can buy. Buying power affects securities values by way of the discount rate (Nguyen, 2018). When inflation is high or rising the future dividends or interest payments from an investment are worth less. Consumer buying power is a vital element for small businesses to understand so that they can effectively price, sell and market their products (Nguyen, 2018). It is essentially a consumer's ability to make a purchase with the amount of money they have. Typically the higher the income a consumer has, the higher the buying power they have. In Zimbabwe the situation is different in the sense that people are getting less income which may be lessening their buying power in most of the retails thereby affecting their loyalty to product brands. Product performance have an influence to customer loyalty.

\section{Switching costs}

Switching costs are the costs that a consumer incurs as a result of changing brands, suppliers or products. The switching costs make the costs of products expensive for a customer, which makes 
it difficult or expensive for customers to change brand time to time so they try to find another brand that has the ability to satisfy their needs in more effective way (Lansing, 2011). As such the consumers are faced with a lot of problems which include emotional, technical, financial, operational and psychological problems while experimenting with new products or services in order to get those that perform closer or the same as the product brands they are used to (Nguyen, 2018). However, there is greater chance that the customers will remain loyal to one brand when process of switching costs is in favour of the customers. Instability of prices may lead to decreased purchasing power among the consumers when their source of income remains stagnant. Decreased purchasing power for consumers may lead them to seek alternative product brands they can afford (Risdianto, 2017). However, when consumers' income is reviewed to match product price hikes, most consumers may continue to purchase product brands they are used to. Product suppliers may also take advantage of price instability by introducing alternative new products with improved performance. When the market gets flooded with improved products brands, it may not be certain that consumers keep loyal to the old brands, which is the case with the fashion market in Zimbabwe. The other factor that affects customer loyalty is inflation.

\section{Inflation}

Inflation is a general rise in the price level of an economy over a period of time (Baye, 2010). When the general price level rises, each unit of currency buys fewer goods and services. Causes of inflation are high demand and low production or supply of multiple commodities creates a demand supply gap which leads to hike in prices (Baye, 2010). Excess circulation of money leads to inflation as money loses its purchasing power. This also affects the cost of living in a country. When inflation is high, the cost of living gets higher as well, which ultimately leads to a deceleration in economic growth (Baye, 2010). This indicates that if the cost of living gets high in the country, it also affects the level of customer loyalty to fashion products as the purchasing power may decrease.

High inflation, stimulates wage growth, a rise of wage adjusted for inflation, often expressed in percentage. It is one of the main indications to measure economic growth for a long term since it reflects the consumer's purchasing power in the economy as well as the level of living standards (Choi, Laibson, Madrian \& Metrick (2004). Workers may seek larger wage increases to compensate for the effects of higher inflation on their purchasing power. In turn higher wage growth raises firms' costs which may lead firms to raise prices further. Due to economic hardships in Zimbabwe higher wage growth raises firm's costs which are leading to increased product prices.

\section{Market interest rates}

Market rates are rates of interest paid on deposits and other investments, determined by the interaction of the supply of demand for funds in the money market. This rate is driven by multiple factors, including central bank interest rates, the flow of funds into and out of a country, the duration of deposit and size of deposits (Bryman, 2007). Market interest rates are determined in large part by central banks who actively commit to maintaining a target interest rate. They do so by intervening directly in the open market through open market operations, buying or selling treasury securities to influence short term rates. When market interest rates increases the amount of money that consumers can spend decreases. Consumers still have to pay their bills. When those bills become more expensive households are left with less disposable income, therefore this may 
7 | Exploring Factors Leading to Customer Loyalty to Fashion Brands: A Case Study of Harare, Zimbabwe

affect the level of customer loyalty for various product such as fashion brands, cleaning materials and others. The other factor that affects customer loyalty to fashion brands is buying power of an individual.

\section{Product performance}

Product performance is described as the response of a product to external actions in its working environment (Nguyen, 2018). The performance of product is realized through the performance of its constituent components. In order to keep a business successful the fashion retailers need to make sure that the products are selling well. Product performance enables the fashion retail shops rank product sales based on revenue performance. This allows the fashion retails to inform the sales team about the products that are selling well, so that they can determine which products are failing .This way they can resonate with the customers. The product performance is a great way to keep track of the number of products that are sold and assess level of product sales.

\section{Decrease in the drive to repeat business}

Repeat business is when customers shop with your company repeatedly. If there is customer loyalty, loyal customers are the most likely to keep coming back to purchase from the business. Loyal customers are more likely to drive repeat business, making retention of loyal customers critical (Shamini, 2018). In the case of decline in customer loyalty the retails of fashion brands may fail to repeat business. It is incredibly difficult to earn a sale from a customer. Depending on the industry and the price point of products, it would take weeks or months to encourage a customer to do business with a brand. One of the top reasons repeat business is important is that most businesses are built with the help of loyal customers who shop with them regularly. However, if there is a decline in customer loyalty, this means that it will be difficult for fashion retailors to be able to drive repeat business. Repeat business has got benefits of allowing retailors to make additional money. Customers are more likely to spend extra money on brands they feel they can trust and rely on. However, if there is decrease in drive to repeat business it means customers will no longer be loyal to the brands. Decrease in drive to repeat business is usually caused by failure to return customers to continue buying the same brands offered by retailers. Decrease in revenue also affects customer loyalty to fashion brands.

\section{Decrease in revenue}

Revenue decrease is caused by a number of reasons. Manufacturing or delivery problems result in reduced product availability. When consumer tastes change demand for your goods may decline. Economic conditions force consumers to spend less on discretionary purchases, all of these lead to revenue decrease. Most of the fashion retails will not be able to increase revenue from sales of fashion brands due to decrease in customer retention. In essence, once a customer likes and trusts the quality of a brand, they are more likely to purchase in higher quantities (Susanti, 2020). However, the frequency in the purchase of the same brand may be affected by the decrease in revenue. Customers may continue to purchase the same product brands with reduced frequency reflecting loyalty to the brands.

\section{Closure of fashion retails}

Success in the retail business is not an easy matter to achieve lately. There are a lot of challenges that have to be overcome to survive a line of business (Ahamad, 2018). The issue of sustainability 
is one of the factors that lead to closure of fashion retails. As consumers become savvy to the severity of fashion's environmental footprint, they will demand more responsible production. Retailers will be forced to be more creative with how they meet customer demands so as to fight the problem of shutting down and not being able to make profits and keep the business viable (Ahamad,2018). Ragel (2018) highlighted that saturation also affects customer loyalty to fashion brands as such, retailers have to do more to stand out. Customers now have access to a wide sweep of brands and products therefore this means that fashion retails will also have to stand out so as to keep up quality products that will attract customers so that they keep their customers and generate more revenue to keep up the retails functioning (Ragel, 2018). Emerging of other competitors with fast clothes also give threats to fashion retails as this gives a question as to if customers will keep on purchasing fashion brands from the fashion retails or they will go for fast and cheaper products.

\section{Strategies to maintain customer loyalty for fashion brands}

Strategies which help to maintain customer loyalty include creation of brand ambassadors, improving employee morale and rewarding the loyal customers (Sumarwan, 2020).

\section{Rewarding customers}

Rewarding customers is the most essential tools for increasing customer loyalty because the customers are those, who first experience the products or services and this impact on how many customers want to come back and interact with a company again (Sumarwan, 2020). The customers always want to buy from suppliers who know them and their needs. The key rule of building customer loyalty is serving the customers with excellent products according to their experiences. A study by Ragel (2018) reflects that there is trust in an interpersonal relationship between customer-contact employees and customers which has a positive effect on customer satisfaction, which in turn, leads to brand loyalty.

Rewarding customers is another way to retain customers by giving free gifts and extra products to motivate them to keep on purchasing products thus maintaining their loyalty (Ahamad, 2018). Rewarding customers can be used to get the customers repeat their behavior which means providing them with more business. This also attracts other customers as they will be motivated to purchase more goods so as to acquire free gifts. Customers want to feel appreciated. After all, they can choose to spend their money anywhere and they will choose fashion brands that are rewarded well. Rewarding customers for their loyalty and frequent engagement with fashion brands can help distinguish fashion brands from other competitors and also make customers feel valued (Bernazzani, 2017).

\section{Improving employee morale}

Ragel (2018) explains that employee morale is the attitude and overall outlook of employees during their association with an organization or business. This strategy leads to an increase in productivity and efficiency in the workplace. It will also lead to attract and retain top talent. A company may go through bankruptcy but with employee morale the employees will put their heads together and strive to prevent the company from falling (Ragel, 2018). Therefore, improvement of employee morale can motivate workers to do their best in retuning customers so as to keep their loyalty. 
9 | Exploring Factors Leading to Customer Loyalty to Fashion Brands: A Case Study of Harare, Zimbabwe

\section{Creation of brand ambassadors}

A brand ambassador is someone who embodies the brand that he or she will be endorsing, influencing consumers and raising awareness (Meesala, 2018). Brand ambassadors champion a brand, establishing the credibility of the product amongst the correct demographic and engage customers through experience and satisfaction (Becker, 2018). They also serve the purpose of ensuring that customers who engage with the brand will remain loyal. Brand ambassadors give fashion brands a boost on social media, spread positive messages and influence consumer sales. Not only will loyal customers keep coming back, they also spread brand awareness through word of mouth as they tell friends and family about the business and products essentially advertising and spreading good grace on the products (Paul, 2018). Existing customer referral help bring in new customers, making loyal customers brand ambassadors of sorts. Having brand ambassadors can be far more cost -effective than traditional ads and marketing and sales. While some brand ambassadors may be compensated with free products or gift cards, the most successful ambassadors tend to be those whose biggest motivation is to see the brand grow (Meesala, 2018).

\section{Promotions}

Promotion is the voice of the company which sends out the brand's message loud and clear to the audience (Paul, 2018). Promotions increase brand awareness, provide appropriate information, increase customer traffic and build sales and profits of the company (Paul, 2018). Promotions draws pay attention to the brands and services with the goal of boosting sales. It also convinces people to try a new product at least once. The section below presents the methodology of this study.

\section{Methodology}

This study made use of the qualitative research approach which enabled the researchers to gather rich data from participants in situ. The study employed a descriptive research design which made it easier for the researchers to collect detailed information regarding the factors that lead to customer loyalty to fashion brands in Harare, Zimbabwe. The sample for this study comprised of five fashion retail shop management personnel and ten fashion customers, account holder, and non-account holders (walk in client) for selected fashion retail outlets in Harare, Zimbabwe. Purposive sampling was utilized to select participants who were able to disclose relevant information. Data for this study was collected using face- -to- face individual interviews and focus group discussions to triangulate the methods in order for the findings to be trustworthy. Booking for Face-to face individual interviews and focus groups enabled research participants to be prepared for the interviews. Permission to conduct this study was sought from the Department of Clothing Textile Technology who issued the researchers with a reference letter. The researchers sought permission to carry out the study with the targeted fashion retail shops. A pilot study was conducted in order to evaluate feasibility, time, cost, adverse events, and improve upon the study design prior to the performance of a full-scale research. The researcher took two participants from the managers and three from the customers for pre-testing of the research instruments before the actual study was conducted. These participants were not part of the actual group which was going to be interviewed for this study. The pilot study enabled the researchers to improve the interview guides being assisted by other research experts. The interviews would take thirty to forty- five minutes with one individual. The focus group took one hour. Data was analyzed 
thematically in line with the research questions. In conducting this study, the researchers followed the research ethics. This research was conducted with the approval of organization officials and the participants' consent. The researcher made sure that the research participants were fully informed about the nature and purpose of the study. The researchers made use of various ways to encourage the people to participate voluntarily and free from coercion. The researcher informed participants that the information they supplied to the researcher shall be kept confidential for educational purposes only. The names of the participants were not revealed to ensure anonymity of respondents. The researchers allocated codes to the participants M1 to M5 for managers and $\mathrm{C} 1$ to $\mathrm{C} 10$ for the fashion customers. The next section presents the findings of the study.

\section{Findings and discussion}

\section{Demographic data of participants}

Most of the participants for this study were in the age range of thirty-six to forty-five years (six), five were in the age range of twenty-six to thirty-five, two in the age range forty-six to fifty years and one participant in both age ranges of eighteen to twenty five and fifty-one and above. Researches show that age diversity can improve organizational performance and contributions (Pana, 2013). This is so because it brings in greater creativity, innovation and more ideas from all age groups.

Due to age diversity it was easier for the researchers to gather information by meeting participants of different age groups who had different views based on different shopping experiences (Washington, 2013).The young tend to go along with current trends whereas the elderly may purchase a brand basing on their experience in using the product. The aged may hesitate to try to use or purchase new brands.

The study catered for both males and females since it engaged eight female and seven male participants. According to Correll (2017) having a mixture of gender brings substantial potential benefits such as better decision making, greater creativity, innovation and more ideas that help both the firms and customers.

The qualifications of the participants ranged from PhD, Master's degree, Undergraduate degree to Diploma. Well-educated consumers and retail shop managers have better understanding in making valid decisions and more knowledge in terms of handling of customers to keep them loyal to existing fashion brands respectively. According to McIntyre (2018) education is the ability to listen to almost anything without losing temper or self-confidence. The section below presents an analysis of the factors that lead to customer loyalty to fashion brands.

\section{Factors that lead to customer loyalty}

From the findings of the study it was established that, customer satisfaction, customer wages, disposable income, buying power, inflation rate, market rates and demographics were the factors leading to customer loyalty to fashion brands. These factors are going to be explained in the sections below.

\section{Customer satisfaction}

During interviews, it was revealed that customer satisfaction leads to customer loyalty to fashion brands. One of the customers mentioned that: 
11 Exploring Factors Leading to Customer Loyalty to Fashion Brands: A Case Study of Harare, Zimbabwe

"I usually repeat buying a brand when I am satisfied that it's a worth buying product in terms of durability and aesthetics." (C3)

On the same issue of customer satisfaction, another customer echoed that:

"I buy a product when it is functional for the intended purpose and is affordable."(C6)

The above statements by fashion customers reflect that customers have some factors they consider for them to be loyal to some fashion products such as durability, functionality and affordability of the fashion product. Thus, Customer satisfactions vary according to each customers' needs. An individual customer may value fitness of a fashion product more than the product's durability. Some customers may consider functionality of the product ignoring the product's aesthetic value. (Maslam, 2015) holds the view that price, value and availability of products to customers' expectation have a bearing on creating customer satisfaction The constant satisfaction usually determines customer loyalty towards the products or services. And it's cheaper to make satisfied customers happy (Zeleke, 2015). The reason being that when customers get good quality products with minimum price then high customer satisfaction follows that leads to elevated customer loyalty. This situation also builds a close relationship between customers and suppliers. However, when the market gets flooded with new product brands, customer loyalty to the original brands may be affected as the customers may go for the new products.

On the same issue of customer satisfaction, one of the participants indicated that the issue of sizes hindered customers 'loyalty to fashion brands. One Fashion customer highlighted that that:

"Several times, I failed to get my size from shop B thus when I stopped visiting this shop for buying and went straight to shopping malls for second hands and got my sizes. "(C4)

On the same issue one of the managers hinted that:

"Some customers leave our fashion brands because of failing to get their sizes" (M4)

From the above issues raised it shows that sizes which were not available for the plus size made most customers to ending up not buying from fashion retails and rather go to other shopping malls where fast fashion clothes were sold. The fast fashion clothing product were said to be very unreliable brands as they were not durable. This means that fashion retailors should thrive to maintain customer loyalty by providing the best unique fashion brands. Customer wages came up as another factor which leads to customer satisfaction.

\section{Customer wages}

Most of the fashion customers pointed out that customer wage growth raises firm's costs which may lead firms to raise prices further therefore affecting customers of fashion brands as well. Participants pointed out that the level of wages also affects consumer spending. One of the interviewed customers revealed that:

My package is reasonably good, so I buy those fashion brands I like even for my family from the same expensive shop." (C2)

On the same issue another customer reiterated that:

"Personally, I do not buy fashion brands because my salary does not allow such luxury." (C1) 
The above explanations means that when wages are progressively rising, consumers mostly have more flexible income to spend. If wages are not increased demand for optional consumer goods is likely to decrease. Managers also supported this as they said that the level at which customers bought fashion brands in their retails contributed to them increasing their prices as they will be aiming to earn more profits. By increasing prices demand for optional goods would then fall as consumers will be concentrating on paying basic commodities such as food. This means that customer wages affect customer loyalty to fashion brands ether negatively or positively. Therefore individual wages should be high for them to be loyal to fashion brands in the various fashion retail shops.

\section{Disposable income}

It also emerged from the findings of this study that disposable income is one of the factors that lead to customer loyalty to fashion brands. Customers pointed out that when they have left over money after paying all the essential bills, that's when they can think of going to purchase the fashion brands they will be in need of. One of the customers pointed out that:

"When I am well paid that my salary can cover all the basics, surely I use some of the left over funds to buy my special fashion brands from the reputable shops I usually buy from. "(C6)

The above statement was supported by one of the managers who said that:

Those with better salaries as noted from their pay slips keep on coming to buy our fashion brands currently. (M4)

The above statement shows that disposable income have a bearing on customer loyalty to fashion brands. It means that when customers are well paid they have extra money to spend on fashion brands they like from those shops they used to visit. This shows that people need to be well paid for them to have left over finances to buy the fashion brands they need from the shops they favour. Creswell (2016) explained that if disposable income increases, households have extra money to spend which naturally leads to growth in consumption. This money is of much influence to customer loyalty because it determines the amount of money used to spend on fashion brands by customers. Disposable income has got factors influencing it which can also lead to decline in customer loyalty. (Sawyer, 2008) also indicated that in a situation where disposable income depreciates it affects the buying behaviour of customers which also affects fashion retailors' business performance. Chetty (2013) echoed that Unemployment causes a drop in income. (Noel, 2017) also explained that household final consumption expenditures may decrease when they are not employed. When household final consumption expenditures decrease the fashion retails get affected in the sense that consumers may go for basic goods only. Thus customer loyalty to fashion brands gets affected negatively. Buying power is another factor that was revealed as affecting customer loyalty to fashion brands.

\section{Buying power}

Most fashion customers indicated that buying power controls their ability to purchase the same fashion product brands repeatedly. The interviewed fashion customers explained that the higher the income they have the higher the buying power they will be allocated in higher purchase shops. On the issue of buying power, one of the customers highlighted that: 
"

When my salary is high, I get a good buying power but when I am paid less like now, the buying power is meaningless for example one time I was given 3000 when the shoe I wanted was costing 5000, so I left the shop"( C 8).

Regarding the issue of buying power, one of the managers explained that:

"Those customers whom we give less buying power usually end up leaving the fashion brands since it will not be enough".(M3).

The above explanation reflects that when an individual' buying power is less, customers will stop being loyal to fashion brands since their buying power will not be able to meet the charged prizes. As a result they leave the shops and look for other alternatives. This means people should be well paid to get better buying power for them to be loyal to some fashion brands. However, from the literature Kuwaza (2019) mentions that most of the customers in Zimbabwe are under paid which indicates that it strains most of the customers' buying power thus affecting their ability to purchase fashion product brands repeatedly. This end up affecting their loyalty to desired fashion brands. In support of this managers for the sampled retail shops revealed that the rate at which their customers were purchasing clothing in their shops had decreased to a greater extend showing that most of the customers were no longer considering fashion brands like they used to do. This reflects that when customers have very little wages their buying power decreases resulting in them, not able to keep on buying the fashion brands they used to purchase. The managers also pointed out that the situation in Zimbabwe was different as customers were getting less income in their different working places which was lessening their buying power in most of the fashion retails thereby affecting their loyalty to fashion brands. It was found that most customers were not able to use the minimum buying power they have in fashion retails to buy fashion brands. They rather opted for other options like buying second hand clothing. The managers argued that most of their customers could not afford to purchase the exclusive clothing brands in their shops due to financial constraints. The customers' failure and reduced rate in purchasing their usual clothing brands indicated a decrease in brand loyalty consumption. Inflation rate was also indicated by the participants as one of the factors that lead to customer loyalty and it is presented below.

\section{Inflation rate}

Most of the participants showed that increase in inflation influenced customer's level of loyalty to fashion brands. They indicated that when inflation rates keep on increasing, the prices of fashion brands also rise up and they will not be able to keep on buying them and they end up opting for cheaper fashion products. During interviews, one of the customers echoed that:

"Nowadays the rates of inflation is unbearable, as such I have since stopped buying expensive brands from the shops I used to. "(C3).

The above explanations from the participants reflect that high inflation rates affect customer loyalty to fashion brands. when the rate of inflation is stable or low customers become loyal to fashion brands but when it rises drastically customers stop buying those fashion products they valued most. Kuwaza (2019) also explained that economic hardships in Zimbabwe and the ever increasing inflation rates triggered a rise in prices therefore, customers were not able to purchase fashion brands with the salaries they received. Backing this point, the 
managers raised that due to high inflation, materials were expensive to buy causing product prices to go up affecting customers' buying power. Thus by raising prices this failed to accommodate other customers who could not afford most of the fashion brands offered by fashion retail shops. This means that the government should take measures to stabilize the inflation rates in the country so that prizes become stable to enable fashion customers to become loyal to those fashion products they used to buy. The next paragraph is going to discuss market rates as one of the factors that lead to customer loyalty

\section{Market rates}

Most of the customers during focus discussions acknowledged that market rates influenced customer loyalty for fashion brand consumption. Increased market rates affected customers as they were forced to save more and purchase less fashion products. This resulted in customers buying fewer items per purchase. One of the participants who was interviewed explained that:

"These market rates are too high and they affect me greatly. I can no longer afford to buy the number of fashion brands I used to." (C9)

One of the managers explained that:

"These days most of the customers do not have extra funds to purchase our fashion brands, they are focusing on basic bills like Zesa, school and fees, rentals and food. "(M1)

The excerpt above reveals that market rates influence customer loyalty to fashion brands. When market rates are high they reduce the amount of money an individual will be having and when they are low people will be able to purchase more fashion products thereby maintaining their loyalty to some favourable fashion brands. In support of the above statement one of the authors explained that: when market interest rates increase the amount of money that consumers can spend decreases (Bryman, 2007). This was supported by the managers as they noted that customers still had to pay their bills although those bills had become more expensive for customers to remain with adequate disposable income for purchasing other things like clothing. Therefore, this affected negatively the level of customer loyalty to fashion brands. Managers also revealed that due to economic constrains most of the customers reduced their buying behaviour as most of the customers were buying clothes only on festive season and not on monthly basis like they used to do before. Basing on this discussion the Government of Zimbabwe should keep on controlling market rates so that customers are able to buy fashion brands they wish without problems. This is so because the black market rates are always hiking and makes individuals to face challenges in terms of stable finance to pay their bills and extras to buy those fashion brands they used to purchase.

\section{Demographics}

Demographics was also a factor that was revealed by most of the participants as leading to customer loyalty to fashion brands. Most of the interviewed participants pointed out that, the age of customers influenced customer loyalty in fashion product consumption. The participants indicated that generally, the older customers were likely to be loyal to specific fashion product brands longer than the younger customers. They explained that the younger customers always want to test the new clothing brands since they have not developed confidence in use of products they used for a short time. One of the older customers mentioned that: 
"\{Usually I want to keep on buying the fashion brand that I know of its performance in use." (C6)

On the same issue a younger customer participant hinted that:

"I always look for new bands from different shops since I want to have a feel of the current trends in terms of fashion." (C10).

On the same issue of demographics one of the managers during interviews revealed that:

"Manufacturers of these fashion brands are always producing the same line of styles which most of the younger customers do not favour, they want variety."(M1).

The statements given above reflect that age has an influence on customer loyalty to fashion brands. The older people always want to keep on repeating purchases of fashion brands they have bought and used before and are happy with their performance. In contrary, the younger generations go for the varied fashion brands just to have an experience with each new coming brand. This shows that age affects customer loyalty to fashion brands both positively and negatively. Fidelity (2019) hold the view that most young customers are going for fast fashion which is available in shopping malls as such products are very attractive although not durable. Managers however, seconded and also added another problem which was influenced by demographics as a factor that affected customer's loyalty level for fashion product brand consumption. Manufacturers were said to be producing the same line of styles which most of the younger customers do not favour. This means that manufacturers of fashion brands should be very creative and be able to come up with those unique fashion brands that are appealing to the teenagers for them to become loyal to the fashion brands.

\section{Strategies that can be put in place to maintain customer loyalty to the fashion brands offered by clothing retail outlets in Zimbabwe}

From the findings of this study it was established that customer loyalty to fashion brands can be enhanced through the use of promotions, creation of brand ambassadors, rewarding loyal customers. These strategies are discussed below.

The majority of the interviewed participants indicated that most fashion retail shops used promotions as a strategy to maintain customer loyalty. One of the interviewed managers echoed that:

"To maintain customer loyalty to our fashion brands here we hold some brand promotions several times."(M4)

On the same issue another interviewed customer indicated that:

"All the fashion retail shops that I buy from use promotions to attract us as their long saving customers using reduced prices."(C2).

This shows that it is the voice of the company which sends out the brand's message loud and clear to the audience. Most of the retails made use of promotions to attract their customers. Promotions are meant to increase brand awareness, provide appropriate information, increase customer traffic and build sales and profits of the company (Ibojo, 2015). It also shows that the strategy of conducting promotions which was used by most of the fashion retailers motivated the customers 
to buy fashion brands continuously. The customers and managers also revealed that due to less income among most of the customers most of them failed to acknowledge promotions being put up by the fashion retailers. Very few customers end up buying fashion products during band after promotions. However, having those few going for the products is better than none as the situation may improve with time.

\section{Improving employee morale}

Interviewed managers indicated that improving employee morale is one of the strategies that was used by fashion retail shops to maintain customer loyalty to their fashion brands. One of the managers mentioned that:

"We often motivate our employees by giving them free lunches, sometimes unexpected bonuses just to make them happy"(M1).

The above statement reflects that some of the retailors of fashion brands retain their customers by improving theirs workers morale first. If workers in the shops are happy it means they will also work well with the customers giving them the required services when they visit their shops. Nguyen (2018) states that improving employee morale is the attitude and overall outlook of employees during their association with an organization or business. Employee morale can motivate workers to do their best in returning customers so as to keep the business viable. However, from the results gathered from the managers it showed that when employees receive unexpected salaries in the form of bonuses, they end up not doing their duties appropriately. By this managers also raised a problem whereby workers were facing problems of being loaded with a lot of duties at once due to lack of enough employees in retail shops. This was so due to reduction of workers by fashion retail shops so that they are left with workers that they are able to pay although on minimal pay rates.

Rewarding customers was another strategy that was revealed by the managers and the customers during interviews this is discussed in the following section.

\section{Rewarding customers}

Rewarding customers is another way of motivating customers which was indicated by the participants. Findings reflected that this strategy It was used by most fashion retail shops by giving free gifts and extra products to motivate them to keep on purchasing fashion brands. One of the interviewed managers explained that:

"Due to economic challenges we are no longer giving gifts to our clients as we used to do." (M3)

The above statement reflects that rewarding customers was no longer used to attract customers that much. Due to fashion retail shops battling to get enough profit for business they no longer issue out free gifts. To support this, managers noted that it is now difficult to reward their customers as they are not gaining much profit that will enable them to promote the rewarding program.

\section{Maintaining Brand ambassadors}

Most of the customer participants pointed out that brand ambassadors help them to be motivated to buy from fashion retails. This strategy was also revealed by the managers. One of the managers highlighted that: 
"Our brand ambassadors play a critical role in promoting our fashion brands to our customers."(M5)

On the same issue another fashion customer explained that:

"We are loyal to these fashion brands due to the fact that our brand ambassadors help us a lot to keep on liking the fashion brands from the same shops. "(C10).

The above statements reflect that brand ambassadors assist fashion customers to maintain their loyalty to fashion brands. Brand ambassadors serve the purpose of ensuring that customers who engage with the brand will remain loyal (Ahmad, 2018). It shows that most retail shops employ the strategy of creating brand ambassadors so that they can help in returning customers of fashion brands so as to keep a viable business.

\section{Conclusions}

In conclusion the first research question looked at the factors that lead to customer loyalty and the findings show that customer satisfaction, inflation rates, customer wages, buying power, market interest rates, product performance, disposable income and demographics were factors leading to customer loyalty. From the findings these factors were affecting the frequency in which fashion customers were purchasing fashion brands from the fashion retail shops. . The second research question looked at strategies that can be put in place to maintain customer loyalty within the brands offered by clothing retail outlets in Zimbabwe. These include fashion brand promotions, reducing prices and rewarding loyal customers.

\section{Recommendations}

Basing on the findings of the study, the researchers came up with the following recommendations:

$>$ To develop a model or tool that will quickly alert fashion retailers when sales are being affected and their customer retention being a threat to them so that they can adjust and continue operating in situations when customer loyalty declines.

$>$ Introduction of flexible repayment methods in terms of affordable instalment plans.

$>$ The fashion retailers are encouraged to formulate a fashion retailer's board responsible for organizing forums to discuss issues regarding customer brand loyalty.

The following section presents the proposed model that may be used by fashion retailers to enhance customer loyalty to fashion brands 


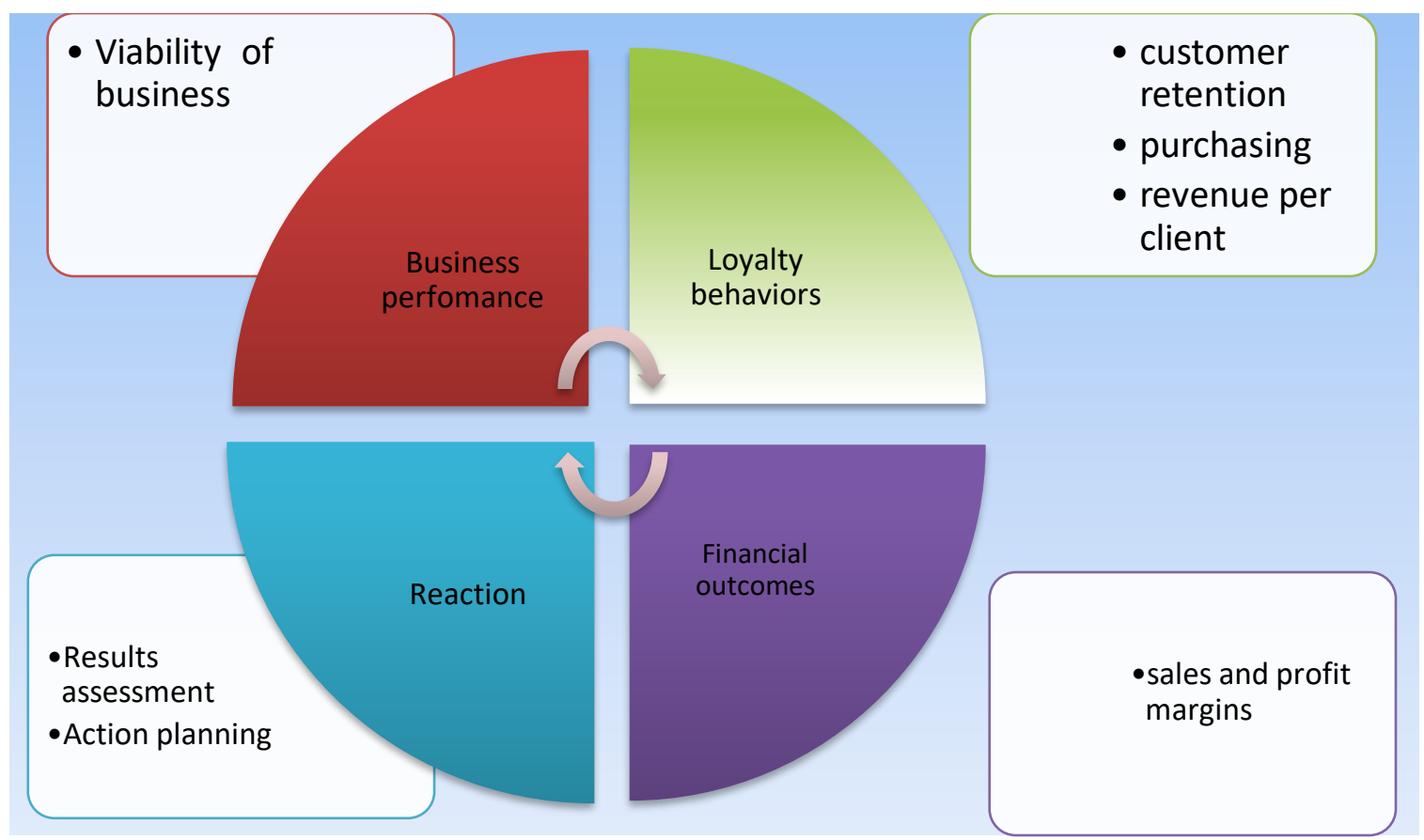

Fig 2. Ndlovu, N., Dandira, T., and Chimbindi, F. (2021)"s Utility cycle matrix model of fashion consumption behavior

The proposed model was derived from the findings of the study and comprises of the reactions that occur in fashion retails according to the buying behavior of customers. The model is called the Utility function cycle matrix of fashion consumption behavior. It consists of determinants and their reactions. This matrix will help fashion retails to be able to analyze the reaction of their customers towards their buying behavior so that they can take action as to how they can maintain loyalty of their customers.

Fashion consumption utility should be derived from satisfaction obtained from making right choices and preferences. The higher the buying behaviour of fashion consumers, the higher they become loyal to the products. The less the buying behaviour of fashion consumers, the less the chances of them being loyal to fashion brands.

Fashion products consumption utility should be derived from the amount of money available to be spent after covering the basic commodities needed for survival of individuals and households which is not being experienced in Zimbabwe. Fashion retails should study their business performance as proposed by the model so as to assess whether they are improving or not by so doing taking into consideration the solutions being proposed by the researchers enhance customer loyalty to fashion brands. Introduction of flexible repayment methods in terms of affordable instalment plans to maintain the utility derived from consumption of fashion brands and keep up with changing global trends thereby improving customer loyalty to fashion brands. The section below presents areas that can be researched further by others in the same area.

\section{Limitations and suggestions for further research}

Since this study was conducted in Harare one of the cities in Zimbabwe, other studies to include other cities in Zimbabwe can be conducted for the results to be generalized. 
It could be also important to research on other variables such as level of customer loyalty to fashion brands in Zimbabwe so that the fashion retailers will be informed of the position of customers regarding their loyalty to fashion brands and be able to plan to improve customer loyalty to their fashion brands.

\section{References}

Akin, T. (2015). Deveoping Theoretical and Conceptual Frameworks. Retrieved from Jedm.oauife.edu.ng Alan, J., Auerbach, \& Raj , C. (2017). In Business and Economics.

Airas, M. (2015). Six reasons customer loyalty is so important (and profitable). Available at: http://www.etuma.com/blog/customer-loyalty-profitable.

Arief , A., Simanjuntak, M., \& Kirbrandoko. (2019). Analysis of Factors affecting the satisfaction and and loyalty of the use of cargo services. Journal of Agricultural and Socio-Economic Sciences.

Ashraf, S., llyas, R. Lmtiaz, M, \& Ahmad, S. (2018). Impact of service quality, corporate image, and perceived value on brand loyalty with presence and absence of customer satisfaction: A study of four service sectors of Pakistan. International journal of Academic Research in Business and social Sciences, 8(2), $452-474$

Baye, M.R. (2010).Microeconomics and business strategy. New York, NY: McGraw-Hill Irwin.

Beard, R. (2014). Customer Satisfaction. Retrieved from ClientHeartBeat: blog.clientheart.com/whycustomer satisfaction is important

Becker. (2018). Methodology proposals for the study of consumer experience. Quantitative Market Research, 465-490.

Bernazzanni, S. (2017). Customer Loyalty. Retrieved from http://blog.hubspot.com/Customer success

Bernheim, D. andRangel, A (2007). "Beyond Revealed Preference: Choice Theoretic Foundations for Behavioral Welfare Economics" Stanford mimeo.

Bruce, L. (2016). Negative personal savings rate: What does it mean? Bank rate. Retrieved from http://www.bankrate.com/finance/savings/negative-personal-savings-rate-what -does-it-mean.aspx

Bonga, W.G and Mlambo, N (2016)."Banks and financial LiteracyEnhancement in Zimbabwe' 'Journal of Economics and Finance, Volume 7, (Mar-Apr)

Choi, J. J., D. Laibson, B. C. Madrian, and A. Metrick. (2004). "For Better or for Worse: Default Effects and 401(k) Savings Behavior." In D. A. Wise, ed., Perspectives on the Economics of Aging, Chicago: University of Chicago Press, 81-121.

Fidelity,M. (2019, December 19). Business. Retrieved from the Newsday: w.w.w newsday.co.zw

Fidelity,M. (2020, October 23). Zimbabwe-Second-Hand Clothes, Cheap Imports Choke Zim Retailers.

Retrieved from the Newsday: w.w.w newsday.co.zw

Griffin, \& Herres, R. T, (2012). Customer loyalty: how to earn it, how to keep it.San Francisco: Jossey-Bass

Houthakker, H. S. 1950. "Revealed Preference and the Utility Function." Economica 17, 159174. 
Ibojo, B. O. (2015). Impact of customer satisfaction on customer retention: A case study of a reputable bank in Oyo. Oyo State, Nigeria. International Journal of Managerial Studies and Research (Ljmsr), 3(2), 42 53

Jack, C. (2021). Taylor Library. 6800 Wydown Blvd. St. Louis, MO 63105 proudly sponsored by the Sisters of St. Joseph of Carondelet.

Kanyenze, G. (2006). The Impact of Economic stabilazation on the wage structure in Zimbabwe. Constrains on the success of structural adjustments in Africa.

Kuwaza, K. (2019). Retrieved from independent Zimbabwe: theindependent.co.zw

Kuwaza, K., \& Ndebele, H. (2016, February 5). Moew Firms shut down' 400 lose jobs. Retrieved from Zimbabwe Independent: theindependent.co.zW

Little, I. M. D. 1949. "A Reformulation of the Theory of Consumer's Behaviour." Oxford Economic Papers 1, 90-99.

Mangudhla, T. (2014, June 27). Textile industry at 10\% capacity. Retrieved from Zimbabwe Independent: theindependent.co.zW

Meessala, A., \& Paul, J. (2018). Service Quality, consumer satiisfaction and Loyalty. Journal of Retailing and Consumer Service Elsevier vol 40, 261-269.

Mpofu, T. (2013). Challenges Faced by the Clothing sector in Zimbabwe. Journal of Business and Management.

Miller, R. \& Washington, K. (2013) Consumer loyalty, Loganville: Richard K. Miller \& Associates.

Mirriam,M. (2020, December 19). The rise and fall of departmental stores. Retrieved from the Herald: theherald.co.zw

Mohammed, Z. (2013). Theory and Practice in Language Studies (Vol, 3, Issue 2) Academy Publication

Mohsan, F.Nawaz, M. M .Khan, M.S. Shallkat, Z.\& Aslam, N. (2011).Impact of customer satisfaction on customer loyalty and intentions to switch: Evidence from banking sector of Pakistan. International Journal of Business and Social Science

Mtomba, V. (2014).Zimbabwe Records 75 Company Closures, Over 9000 Job Losses. (o) www.newsday.co.zw Retrieved 03\05\15 at 1043pm

Mukoshori, S. (2014). Clothing Industry Still In Crisis. (o) www.financialgazette.co.zw Retrieved 03\05\15 at 1023

Nguyen, H.T., Nguyen, H., Nguyen, N.D., \& Phan, A.C. (2018).Determinants of customer satisfaction and loyalty in Vietnamese life-insurance setting. Sustainability

Nyoni, M. (2019). Clothing Industry still in crisis. Retrieved from Financial Gazette: www.financialgazette.co.zw

Pana, L. (2013). Social efficacy by respnsible Management. System Practical Research.

Risdianto, G.E. (2017).Effects of customer satisfaction and switching barrier on customer loyalty with customer trust as moderating variables at Petra Togamas bookstore Surabaya. Journal Management Pemasaran, 2(2), 1-10

Sachikonye, L. M. (2016) Restructuring or Industrializing? Zimbabwe's Textile and Metal

Samuelson, P. A. 1948. "Consumption Theory in Terms of Revealed Preference." Economica 15, 243-253. 
21 Exploring Factors Leading to Customer Loyalty to Fashion Brands: A Case Study of Harare, Zimbabwe

Shamini, H., \& Ragel, V. (2020). The effectiveness of switching barriers on customer loyalty mediated with customer satisfactiion. South AsianJournal of Social Studies and Economics.

Susanti, V., Sumarwan, S., \& Simanjuntak, M. (2020). Rational antecedent framework of brand satisfaction in the industrial market. International review of Management and Marketing.

Zeleke, M. (2015). Influence of quality service on customer satisfaction and loyalty. Saarbrucken: LAP LAMBERT Academic Publishing. 